\title{
Learning Achievement Analysis of Male and Female Students at the PPNS and Polmed to Meet the Global Challenges
}

\author{
Rina Sandora ${ }^{1}$, Budi Indra Syahdewa ${ }^{2}$ \\ ${ }^{1}$ Shipbuilding Institute of Polytechnic Surabaya, Surabaya, Indonesia, \\ ${ }^{2}$ Medan State Polytechnic, Medan, Indonesia \\ rinasandora@gmail.com
}

\begin{abstract}
Industry revolution 4.0 era provides opportunities as well as threats for the students and alumni graduated from vocational education. Man roles are gradually taken by automatic machines. Consequently, unemployment is increasing. This certainly will contribute to the either local or national problems. Therefore, vocational education students have to intensify their learning achievements. This study discusses the learning achievements of the male and female students at the Shipbuiding Institute of Polytechnic Surabaya (PPNS) and Medan State Polytechnic (Polmed). The analysis of learning achievements in this study used the documentation data of the GPA in scale 4, taking the whole population either male $(M)$ or female $(F)$ in the academic year 2015/2016, 2016/2017, and 2017/2018. In the last three years, total PPNS's graduates are 1959 (1418 male, 541 female) and Polmed's are 5938 (2821 male, 3117 female). Based on the descriptive quantitative analysis, the average of learning achievements at PPNS shows that accumulated GPA of the female students' is 3.39 > male students' 3.28. While at Polmed, it is GPA of female students' is 3.27 > male students' 3.14. Total of students is still gender imbalance referring to the graduates data in year 2018 for PPNS' Welding Study Program in which having only two female students with average GPA 3.41 and 53 students with average GPA 3.15, meanwhile at Polmed, the total students with largest gap in gender occured at the Mechanical Engineering Study Program with total of male students 240 (average GPA 3.10) and female students only 11 (average GPA 3.20). This result indicates that in these two vocational educational institutions, e.i. PPNS and Polmed, the learning achievement of female students is betterand more competitivable than the other.
\end{abstract}

Keywords : Index Terms-learning achievement, vocational education, accumulative GPA, male and female students, descriptive quantitative analysis.

\section{INTRODUCTION}

Higher educational institutions play a very important role in creating qualified graduates and human resources that compete in the era of industrial revolution 4.0. [1]. They have a large responsibility for their graduates either male or female to be ready to face global challenges and engage in various roles [2]. The fact is that there are still many companies who doubt the readiness of women to fill their roles in more important fields than men. While women also have abilities comparable to men [3]. The steps taken by universities are to provide academic skills and abilities. Academic ability is a person's ability and proficiency in the academic field. This academic field includes the sciences that exist in formal education, such as various courses that exist in formal education.

This academic ability leads to IQ (intelligence Quotient) abilities that each person has. The learning achievements achieved by students in higher education can be expressed by expressing the ability of the academy. This achievement is manifested in quantitative values or numbers obtained during the midterm exam, as well as the final semester exam to become a Grade Point Average (GPA) every semester until it becomes a GPA at graduation. Various activities related to the measurement of learning achievement, from the beginning students should familiarize themselves with setting targets for learning achievement. Preparation of this target has an important meaning for each student because it can help students to plan, implement, and evaluate the desired achievement of learning achievement at the same time as an effort to motivate themselves for the desired achievement. The preparation of targets is related to the possible choice of majors when continuing their studies and career choices when graduating from college.

Learning achievement needs to be analyzed both by the students concerned and by the respective universities as evaluation of the 


\section{Tibuana}

Journal of applied Industrial Engineering-University of PGRI Adi Buana

$p$-ISSN 2622-2027

$e$-ISSN 2622-2035

academic abilities that underlie success including career readiness in both male $(\mathrm{M})$ and female $(\mathrm{F})$ graduates. GPA is often one of the requirements when applying for a job in a company. Every student who graduates from vocational education will get a diploma along with academic transcripts every semester and become a graduation grade point average (GPA) and will be given a certificate of competence. This study aims to look at the learning achievements of male and female students at the Surabaya State Shipping Polytechnic (PPNS) and the Medan State Polytechnic (Polmed) from year to year. Using quantitative descriptive analysis methods for all populations [4]. Quantitative descriptive

analysis of learning achievement in this study using documentation data from the Grade Point Average (GPA) of graduates on a scale of 4, processing all populations graduating Diploma III and Diploma IV both male (M) and female (F) students over the past three years, namely 2015/2016, 2016/2017 and 2017/2018 Academic Year. The number of graduates in the last three years in PPNS was 1959 people $($ Men $=1418$ people, Women $=541$ people) out of 14 (fourteen) study programs [5]. Polmed's data is 5938 graduates $($ male $=2821$ people, female $=$ 3117 people) out of 17 (seventeen) study programs [6].

\section{RESEARCH METHODS}

A. Flow diagram

The flow chart in this study can be seen in Figure 1.

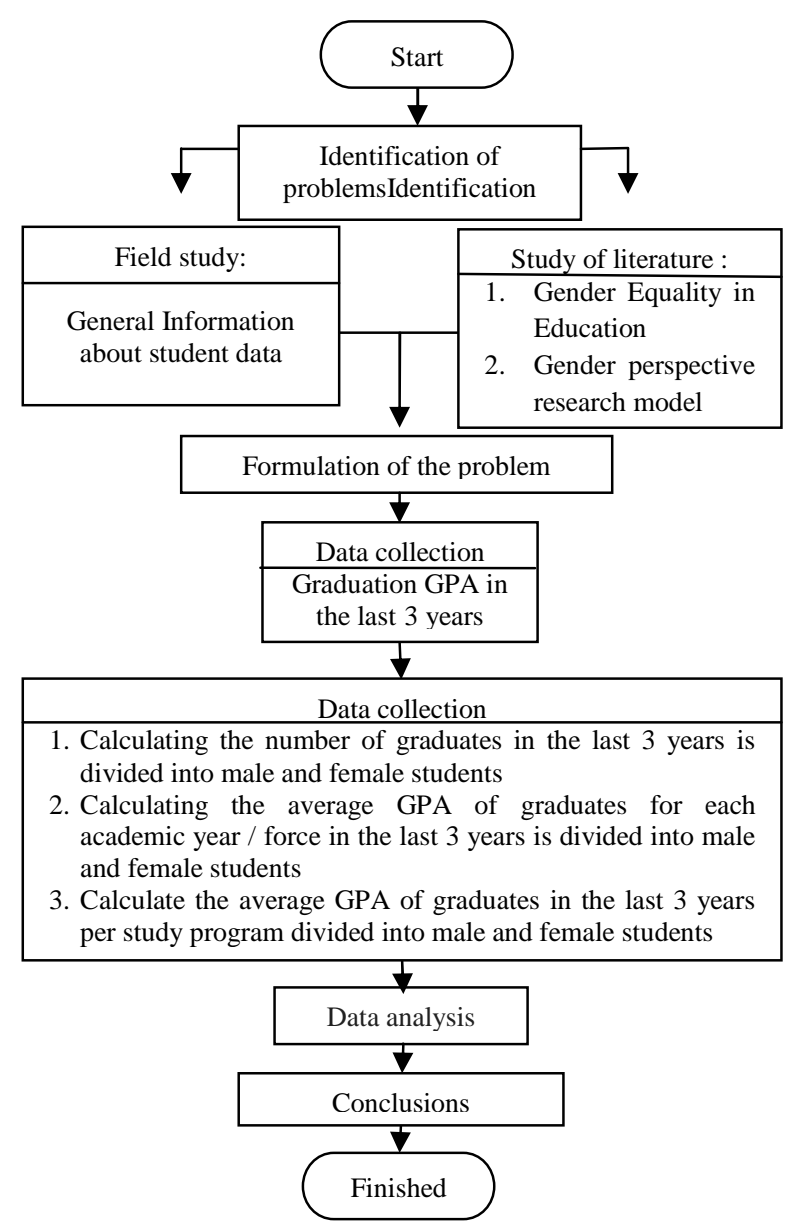

Figure 1. Research flow chart 


\section{Tibuana}

\section{B. Formulation}

The degree of student success in 1 (one) semester is stated in the Semester Achievement Index (IPS). The degree of student success in the cumulative diploma education stage is expressed in the Grade Point Average (GPA). IPS is calculated in the current semester and the GPA is cumulatively calculated from the beginning of the semester to the current semester. Social Sciences and GPA range from 0 (zero) to 4 (four). IPS and GPA calculations use formulas such as formula 1

\section{RESULTS AND DISCUSSION}

This study uses documentation data from the Grade Point Average (GPA) of graduates on a scale of 4 , processing all populations graduates of Diploma III and Diploma IV both male (M) and seen in table 1.

$$
I P=\frac{\sum_{i=1}^{\mathrm{n}} N i \times K i}{\sum_{i=1}^{\mathrm{n}} K i}
$$

Information :

$\mathrm{Ni}=$ The numerical value of the final result of the evaluation of each course taken

$\mathrm{Ki}=$ SKS size for each subject per week

$\mathrm{n}=$ Number of courses

Calculation of the average GPA of graduates uses formula 2

Average GPA $=\frac{\text { Total GPA }}{\text { Number of students }}$

female (F) students for the last three years namely 2015/2016 Academic Year, 2016/2017 and 2017/2018. List of Diploma III and Diploma IV Study Programs in PPNS and Polmed can be

Table 1. List of Study Programs in PPNS and Polmed

\begin{tabular}{cl}
\hline No & \multicolumn{1}{c}{ Study Program at PPNS } \\
\hline & Ship Design and Construction Engineering \\
2 & (DC) \\
& Design and Manufacturing Engineering (TDM) \\
3 & Occupational Safety and Health Engineering \\
4 & Ship Mechanical Engineering (ME) \\
5 & Ship Electrical Engineering (PE) \\
6 & Ship Building Engineering (SB) \\
7 & Welding Engineering (TL) \\
8 & Automation Engineering (TO) \\
9 & Piping Engineering (TP) \\
10 & Business Management (MB) \\
11 & Waste Management Engineering (TPL) \\
\hline No & \\
\hline 1 & Mechanical Engineering (ME) \\
2 & Energy Conversion Engineering (EN) \\
3 & Civil Engineering (SI) \\
4 & Electrical Engineering (EL) \\
\hline 5 & Electrical (Electronica) Engineering (EK) \\
6 & Telecommunications Engineering (TK) \\
7 & Accounting (AK) \\
8 & Banking \& Finance (BK) \\
9 & Business Administration (AB) \\
10 & Information Management (MI) \\
11 & Computer Engineering (CE) \\
12 & Incentive Travel, Convention and Exhibition \\
13 & Services (MICE) \\
& Building Construction Engineering \\
14 & Management (MRKG) \\
15 & Public Finance Accounting (AKP) \\
16 & Finance and Islamic Banking (PS) \\
& \\
\hline
\end{tabular}




\section{Tibuana}

Journal of applied Industrial Engineering-University of PGRI Adi Buana

17 Business Management (MB)

The number of PPNS graduates is divided into male and female students in the 2015/2016,
2016/2017 and 2017/2018 academic years can be seen in table 2.

Table 2. Data on graduates of PPNS students

\begin{tabular}{ccc}
\hline Academic Year & $\begin{array}{c}\text { PPNS (M) } \\
\text { graduates }\end{array}$ & $\begin{array}{c}\text { PPNS (F) } \\
\text { graduates }\end{array}$ \\
\hline $2015 / 2016$ & 473 & 142 \\
$2016 / 2017$ & 451 & 164 \\
$2017 / 2018$ & 494 & 235 \\
Total M\&F & $\mathbf{1 4 1 8}$ & $\mathbf{5 4 1}$ \\
The sum of all & & $\mathbf{1 9 5 9}$ \\
\hline
\end{tabular}

The number of female students in PPNS is less than the number of male students each year.

The number of Polmed graduates is divided into male and female students in the 2015/2016, Table 3. Data on graduate students of Polmed

\begin{tabular}{ccc}
\hline Academic Year & $\begin{array}{c}\text { Polmed }(\mathrm{M}) \\
\text { graduates }\end{array}$ & $\begin{array}{c}\text { Polmed (F) } \\
\text { graduates }\end{array}$ \\
\hline $2015 / 2016$ & 864 & 934 \\
$2016 / 2017$ & 950 & 1026 \\
$2017 / 2018$ & 1007 & 1157 \\
Total M\&F & $\mathbf{2 8 2 1}$ & $\mathbf{3 1 1 7}$ \\
The sum of all & & $\mathbf{5 9 3 8}$ \\
\hline
\end{tabular}

The average GPA of PPNS graduates is divided into male and female students in the academic year 2015/2016, 2016/2017 and 2017/2018 can be seen in table 4

Table 4. Average GPA of PPNS graduates

\begin{tabular}{ccc}
\hline $\begin{array}{c}\text { Academic } \\
\text { Year }\end{array}$ & $\begin{array}{c}\text { Average PPNS (M) } \\
\text { GPA Graduates }\end{array}$ & $\begin{array}{c}\text { Average PPNS (F) } \\
\text { GPA Graduates }\end{array}$ \\
\hline $2015 / 2016$ & 3.29 & 3.46 \\
$2016 / 2017$ & 3.25 & 3.39 \\
$2017 / 2018$ & 3.3 & 3.34 \\
\hline
\end{tabular}

The graphical display for the average GPA of PPNS graduates can be seen in Figure 2.

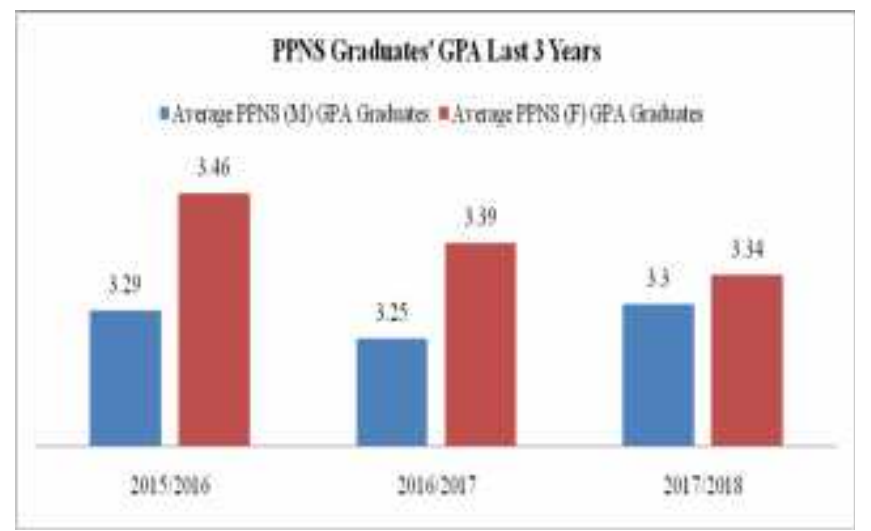




\section{Tibuana}

Journal of applied Industrial Engineering-University of PGRI Adi Buana

p-ISSN 2622-2027

$e$-ISSN 2622-2035

Figure 2. Graph of average GPA of PPNS graduates [5]

GPA difference between male and female PPNS students in 2015/2016 academic year $=0.17$, $2016 / 2017$ academic year $=0.14$ and $2017 / 2018$ academic year $=0.04$.
The average Polmed graduate GPA is divided into male and female students in the academic year 2015/2016, 2016/2017 and 2017/2018 can be seen in table 5 .

Table 5. Average GPA of Polmed graduates

\begin{tabular}{ccc}
\hline $\begin{array}{c}\text { Academic } \\
\text { Year }\end{array}$ & $\begin{array}{c}\text { Average Polmed } \\
\text { (M) GPA } \\
\text { Graduates }\end{array}$ & $\begin{array}{c}\text { Average Polmed } \\
\text { (F) GPA } \\
\text { Graduates }\end{array}$ \\
\hline $2015 / 2016$ & 3.16 & 3.29 \\
$2016 / 2017$ & 3.14 & 3.26 \\
$2017 / 2018$ & 3.12 & 3.27 \\
\hline
\end{tabular}

The graphical display for the average Polmed graduate GPA can be seen in Figure 3 .

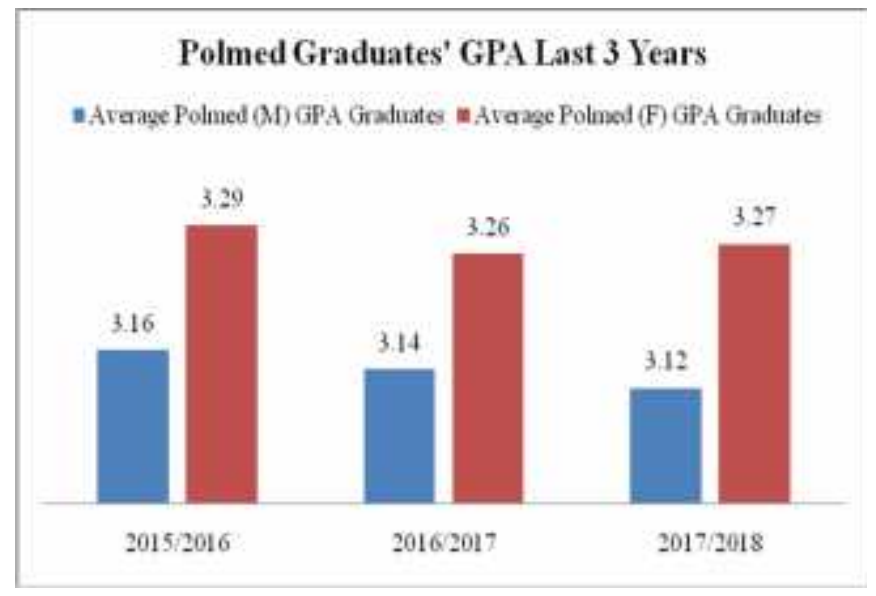

Figure 3. Average graph of Polmed graduate GPA [6]

The average GPA of PPNS graduates is divided into male and female students per 2015/2016,

2016/2017 and 2017/2018 study programs can be

Table 6. Average GPA of 2016-2018 PPNS graduates per study program

\begin{tabular}{|c|c|c|c|c|c|c|}
\hline No & $\begin{array}{c}\text { Study } \\
\text { Program }\end{array}$ & $\begin{array}{l}\text { Graduates } \\
\text { (M) }\end{array}$ & $\begin{array}{c}\text { Graduates } \\
\text { (F) }\end{array}$ & $\begin{array}{c}\text { Total } \\
\text { graduates }\end{array}$ & $\begin{array}{c}\text { GPA } \\
\text { (M) }\end{array}$ & $\begin{array}{c}\text { GPA } \\
\text { (F) }\end{array}$ \\
\hline 1 & $\mathrm{DC}$ & 35 & 21 & 56 & 3.36 & 3.40 \\
\hline 2 & TDM & 37 & 23 & 60 & 3.41 & 3.40 \\
\hline 3 & TK3 & 65 & 56 & 121 & 3.39 & 3.49 \\
\hline 4 & $\mathrm{ME}$ & 85 & 7 & 92 & 3.28 & 3.52 \\
\hline 5 & PE & 46 & 12 & 58 & 3.12 & 3.48 \\
\hline 6 & SB & 50 & 9 & 59 & 3.20 & 3.43 \\
\hline 7 & TL & 57 & 0 & 57 & 3.23 & - \\
\hline 8 & TO & 50 & 11 & 61 & 3.33 & 3.50 \\
\hline 9 & $\mathrm{TP}$ & 48 & 3 & 51 & 3.32 & 3.36 \\
\hline \multicolumn{7}{|c|}{ 2016/2017 Academic Year } \\
\hline No & $\begin{array}{c}\text { Study } \\
\text { Program }\end{array}$ & $\begin{array}{c}\text { Graduates } \\
\text { (M) }\end{array}$ & $\begin{array}{c}\text { Graduates } \\
\text { (F) }\end{array}$ & $\begin{array}{c}\text { Total } \\
\text { graduates }\end{array}$ & $\begin{array}{c}\text { GPA } \\
(\mathrm{M})\end{array}$ & $\begin{array}{c}\text { GPA } \\
(\mathrm{F})\end{array}$ \\
\hline 1 & $\mathrm{DC}$ & 29 & 26 & 55 & 3.33 & 3.38 \\
\hline 2 & TDM & 40 & 17 & 57 & 3.31 & 3.40 \\
\hline 3 & TK3 & 71 & 64 & 135 & 3.30 & 3.43 \\
\hline 4 & $\mathrm{ME}$ & 74 & 6 & 80 & 3.20 & 3.34 \\
\hline 5 & PE & 41 & 20 & 61 & 3.18 & 3.28 \\
\hline 6 & SB & 33 & 9 & 42 & 3.24 & 3.38 \\
\hline 7 & TL & 62 & 4 & 66 & 3.19 & 3.39 \\
\hline 8 & TO & 47 & 6 & 53 & 3.35 & 3.38 \\
\hline
\end{tabular}




\section{Tibuana}

Journal of applied Industrial Engineering-University of PGRI Adi Buana

p-ISSN 2622-2027

$e$-ISSN 2622-2035

\begin{tabular}{ccccccc}
9 & TP & 54 & 12 & 66 & 3.21 & 3.35 \\
\hline \multicolumn{2}{c}{ 2017/2018 Academic Year } & & & & \\
\hline \multirow{2}{*}{ No } & $\begin{array}{c}\text { Study } \\
\text { Program }\end{array}$ & $\begin{array}{c}\text { Graduates } \\
\text { (M) }\end{array}$ & $\begin{array}{c}\text { Graduates } \\
\text { (F) }\end{array}$ & $\begin{array}{c}\text { Total } \\
\text { graduates }\end{array}$ & $\begin{array}{c}\text { GPA } \\
(\mathrm{M})\end{array}$ & $\begin{array}{c}\text { GPA } \\
(\mathrm{F})\end{array}$ \\
\hline 1 & DC & 37 & 38 & 75 & 3.96 & 3.33 \\
2 & TDM & 26 & 27 & 53 & 3.23 & 3.33 \\
3 & TK3 & 72 & 79 & 151 & 3.29 & 3.35 \\
4 & ME & 79 & 9 & 88 & 3.22 & 3.25 \\
5 & PE & 86 & 13 & 99 & 3.21 & 3.23 \\
6 & SB & 31 & 5 & 36 & 3.25 & 3.22 \\
7 & TL & 53 & 2 & 55 & 3.15 & 3.42 \\
8 & TO & 48 & 11 & 59 & 3.34 & 3.35 \\
9 & TP & 44 & 15 & 59 & 3.30 & 3.37 \\
10 & MB & 9 & 17 & 26 & 3.36 & 3.45 \\
11 & TPL & 9 & 19 & 28 & 3.31 & 3.32 \\
\hline
\end{tabular}

The average Polmed graduate GPA is divided into male and female students per 2015/2016,

2016/2017 and 2017/2018 academic year study programs can be seen in table 7 .

Table 7. The average GPA for 2016-2018 Polmed graduates per study program

\begin{tabular}{|c|c|c|c|c|c|c|}
\hline No & $\begin{array}{c}\text { Study } \\
\text { Program }\end{array}$ & $\begin{array}{c}\text { Graduates } \\
\text { (M) }\end{array}$ & $\begin{array}{c}\text { Graduates } \\
\text { (F) }\end{array}$ & $\begin{array}{c}\text { Total } \\
\text { graduates }\end{array}$ & $\begin{array}{c}\text { GPA } \\
(\mathrm{M})\end{array}$ & $\begin{array}{c}\text { GPA } \\
\text { (F) }\end{array}$ \\
\hline 1 & $\mathrm{ME}$ & 201 & 8 & 209 & 3.11 & 3.29 \\
\hline 2 & EN & 50 & 57 & 107 & 3.22 & 3.33 \\
\hline 3 & SI & 88 & 71 & 159 & 3.05 & 3.19 \\
\hline 4 & EL & 85 & 17 & 102 & 3.05 & 3.10 \\
\hline 5 & EK & 68 & 33 & 101 & 3.21 & 3.23 \\
\hline 6 & TK & 43 & 60 & 103 & 3.13 & 3.28 \\
\hline 7 & $\mathrm{AK}$ & 51 & 146 & 197 & 3.21 & 3.31 \\
\hline 8 & BK & 67 & 180 & 247 & 3.21 & 3.36 \\
\hline 9 & $\mathrm{AB}$ & 83 & 204 & 287 & 3.13 & 3.37 \\
\hline 10 & MI & 23 & 61 & 84 & 3.37 & 3.51 \\
\hline 11 & $\mathrm{CE}$ & 41 & 38 & 79 & 3.17 & 3.25 \\
\hline 12 & MICE & 13 & 20 & 33 & 3.19 & 3.48 \\
\hline 13 & TPJJ & 28 & 19 & 47 & 3.18 & 3.15 \\
\hline 14 & MRKG & 23 & 20 & 43 & 2.99 & 3.19 \\
\hline \multicolumn{7}{|c|}{ 2016/2017 Academic Year } \\
\hline No & $\begin{array}{c}\text { Study } \\
\text { Program }\end{array}$ & $\begin{array}{l}\text { Graduates } \\
\text { (M) }\end{array}$ & $\begin{array}{c}\text { Graduates } \\
\text { (F) }\end{array}$ & $\begin{array}{c}\text { Total } \\
\text { graduates }\end{array}$ & $\begin{array}{c}\text { GPA } \\
\text { (M) }\end{array}$ & $\begin{array}{c}\text { GPA } \\
\text { (F) }\end{array}$ \\
\hline 1 & $\mathrm{ME}$ & 199 & 8 & 207 & 3.10 & 3.16 \\
\hline 2 & $\mathrm{EN}$ & 63 & 45 & 108 & 3.15 & 3.35 \\
\hline 3 & SI & 86 & 74 & 160 & 2.92 & 3.10 \\
\hline 4 & EL & 89 & 23 & 112 & 2.92 & 2.97 \\
\hline 5 & EK & 65 & 30 & 95 & 3.05 & 3.15 \\
\hline 6 & TK & 43 & 60 & 103 & 3.01 & 3.17 \\
\hline 7 & $\mathrm{AK}$ & 87 & 199 & 286 & 3.11 & 3.19 \\
\hline 8 & $\mathrm{BK}$ & 83 & 205 & 288 & 3.13 & 3.35 \\
\hline 9 & $\mathrm{AB}$ & 82 & 165 & 247 & 3.04 & 3.30 \\
\hline 10 & MI & 21 & 46 & 67 & 3.29 & 3.48 \\
\hline 11 & $\mathrm{CE}$ & 44 & 38 & 82 & 3.12 & 3.15 \\
\hline 12 & MICE & 29 & 43 & 72 & 3.21 & 3.32 \\
\hline 13 & TPJJ & 30 & 14 & 44 & 3.18 & 3.32 \\
\hline 14 & MRKG & 20 & 22 & 42 & 3.15 & 3.25 \\
\hline 15 & $\mathrm{AKP}$ & 7 & 30 & 37 & 3.38 & 3.38 \\
\hline 16 & PS & 2 & 24 & 26 & 3.45 & 3.55 \\
\hline \multicolumn{7}{|c|}{ 2017/2018 Academic Year } \\
\hline No & $\begin{array}{c}\text { Study } \\
\text { Program }\end{array}$ & $\begin{array}{c}\text { Graduates } \\
(\mathrm{M})\end{array}$ & $\begin{array}{c}\text { Graduates } \\
\text { (F) }\end{array}$ & $\begin{array}{c}\text { Total } \\
\text { graduates }\end{array}$ & $\begin{array}{c}\text { GPA } \\
(\mathrm{M})\end{array}$ & $\begin{array}{c}\text { GPA } \\
(\mathrm{F})\end{array}$ \\
\hline 1 & $\mathrm{ME}$ & 240 & 11 & 251 & 3.10 & 3.20 \\
\hline 2 & EN & 72 & 42 & 114 & 3.10 & 3.27 \\
\hline 3 & SI & 104 & 80 & 184 & 2.95 & 3.20 \\
\hline 4 & EL & 84 & 18 & 102 & 2.97 & 3.07 \\
\hline 5 & EK & 77 & 39 & 116 & 3.24 & 3.30 \\
\hline 6 & TK & 31 & 80 & 111 & 3.25 & 3.29 \\
\hline 7 & $\mathrm{AK}$ & 58 & 185 & 243 & 3.11 & 3.32 \\
\hline 8 & BK & 63 & 217 & 280 & 3.19 & 3.37 \\
\hline 9 & $\mathrm{AB}$ & 74 & 176 & 250 & 3.02 & 3.35 \\
\hline 10 & MI & 28 & 60 & 88 & 3.23 & 3.22 \\
\hline
\end{tabular}

TiBuana, Vol. 03, No. 1, 2020|35 


\section{Tibuana}

Journal of applied Industrial Engineering-University of PGRI Adi Buana

$p$-ISSN 2622-2027

$e$-ISSN 2622-2035

\begin{tabular}{lclllll}
11 & CE & 31 & 49 & 80 & 3.18 & 3.23 \\
12 & MICE & 30 & 55 & 85 & 3.04 & 3.31 \\
13 & TPJJ & 45 & 16 & 61 & 3.06 & 3.17 \\
14 & MRKG & 28 & 19 & 47 & 3.11 & 3.18 \\
15 & AKP & 10 & 47 & 57 & 3.08 & 3.33 \\
16 & PS & 12 & 31 & 43 & 3.24 & 3.45 \\
17 & MB & 20 & 32 & 52 & 3.11 & 3.36 \\
\hline
\end{tabular}

The results of data processing showed that the average GPA of PPNS and Polmed graduates, classified by male and female students per study program for the 2015/2016, 2016/2017 and $2017 / 2018$ academic years, the majority of

\section{CONCLUSION}

Based on the results of data analysis, it can be concluded that:

1. Average Grade Point Average (GPA) of the 2015/2016 PPNS graduates $\mathrm{M}=3.29, \mathrm{~F}=$ 3.46, GPA difference $=0.17,2016 / 2017$ academic year $\mathrm{M}=3.25, \mathrm{~F}=3.39$, GPA difference $=0.14$ and 2017/2018 academic year $\mathrm{M}=3.3, \mathrm{~F}=3.34$, GPA difference $=$ 0.04 . Polmed graduate grade point average (GPA) $2015 / 2016$ academic year $\mathrm{M}=3.16$, $\mathrm{F}=3.29$, GPA difference $=0.13,2016 / 2017$ academic year $\mathrm{M}=3.14, \mathrm{~F}=3.26$, GPA difference $=0.12$ and $2017 / 2018$ academic year $2018 \mathrm{M}=3.12, \mathrm{~F}=3.27$, difference in GPA $=0.15$. The results of the analysis of the average GPA of graduates in PPNS and Polmed show that the average grade of GPA

\section{REFERENCE}

1. Era Revolusi Industri 4.0: Perlu Persiapkan Literasi Data, Teknologi dan Sumber Daya Manusia. (2018). Taken from http://belmawa.ristekdikti.go.id/2018/01/17/e ra-revolusi-industri-4-0-perlu-persiapkanliterasi-data-teknologi-dan-sumber-dayamanusia/

2. H. Nuril, R. Aliyah, S. Pujiati, "Pengembangan Model Penelitian Perspektif Gender", Jurnal Penelitian dan Evaluasi female students' GPA were more superior than the average GPA of male students.

of female graduates is superior to the average GPA of male graduates.

2. The learning achievement of each study program for PPNS and Polmed students in the 2015/2016, 2016/2017 and 2017/2018 academic year shows that the average score of GPA of female graduates per study program is nearly $100 \%$ superior to the average GPA of male graduates male per study program.

3. In the vocational education institutions, PPNS and Polmed, the graduates' GPA of female student is able to compete with the male student's even though in some study programs the number of female students is smaller even in significant inequality.

Pendidikan, Jakarta, nomor 2.2013, Tahun 2017

3. Suryadi, Acee, A. Idris, Kesetaraan Gender dalam Bidang Pendidikan, Jakarta: PT Genesindo, 2004

4. Sugiyono, Metode Penelitian Pendidikan : Pendekatan Kuantitatif, Kualitatif, Bandung, Alfabeta, 2007

5. Cumulative Grade Index data, BAKPSIPPNS

6. Cumulative Grade Index data, BAAKPOLMED 